\begin{abstract}
Iranica
Abstracta Iranica Revue bibliographique pour le domaine irano-aryen

Volume 32-33 | 2013

Comptes rendus des publications de 2009-2010
\end{abstract}

\title{
Adabiyot va shinokhti on (Majmūai maqolot)
}

\section{Evelin Grassi}

\section{(2) OpenEdition}

\section{Journals}

Electronic version

URL: http://journals.openedition.org/abstractairanica/41003

DOI: 10.4000/abstractairanica.41003

ISSN: 1961-960X

\section{Publisher:}

CNRS (UMR 7528 Mondes iraniens et indiens), Éditions de l'IFRI

\section{Printed version}

Date of publication: 1 December 2013

ISSN: 0240-8910

\section{Electronic reference}

Evelin Grassi, « Adabiyot va shinokhti on (Majmūai maqolot) », Abstracta Iranica [Online], Volume 32-33 | 2013, document 444, Online since 01 July 2016, connection on 26 September 2020. URL http://journals.openedition.org/abstractairanica/41003; DOI : https://doi.org/10.4000/ abstractairanica.41003

This text was automatically generated on 26 September 2020.

Tous droits réservés 


\title{
Adabiyot va shinokhti on (Majmūai maqolot)
}

\author{
Evelin Grassi
}

\section{REFERENCES}

Adabiyot va shinokhti on (Majmūai maqolot). Dushanbe, Irfon, 2009, 238 p. [Literature and his knowledge (Collection of articles)]

1 This collection of 27 unpublished articles by Shamsiddin Solehov, professor at the "Rūdakī" Institute of Languages and Literatures (Academy of Science of Tajikistan) in Dushanbe are organized chronologically. Most of them are devoted to 20th century Soviet Tajik literature (Section I: p. 3-150); but a second section (p. 151-238) concentrates on post-Soviet Tajik poetry and prose since the 1990s. The works of Sadriddin Aynī (1878-1954), the author commonly regarded as the founder of modern Tajik literature, are discussed, in particular his realistic prose (p. 10-16). Two other articles focus on the prose-writer Jalol Ikromī (1909-1993) and the image of the town of Bukhara in his works (p. 82-97), and on the poet Loiq Sherali (1941-2000). Another article is about the Soviet-Tajik historian Bobojon Ghafurov (1908-1977) and his role in the development of 20th century Tajik literature (p.63-70). The articles devoted to more general aspects of Tajik literature mostly focus on prose (in particular the shortstory) rather than poetry (p. 203-212); the genre of the short story is worthy of mention during both the Soviet and post-Soviet periods. 


\section{AUTHORS}

\section{EVELIN GRASSI}

Université de Naples 